3 Leenders KL, Wolfson L, Gibbs JM, et al. The effect of L-Dopa on regional cerebral blood flow and oxygen metabolism in patients with Parkinson's disease. Brain 1985;108:171-91.

4 Celsis P, Rascol O, Demonet JF, Agniel A, et al. Effect de la Bromocriptine sur le débit sanguin cerebral dans la maladie de Parkinson. Rev Neurol (Paris) 1988;144:367-71.

5 Fahn S, Elton RL and Members of the UPDRS Development Committee. Unified Parkinson's Rating Scale. In: Fahn S, Marsden CD, Calne D, Goldstein M. eds. Recent Developments in Parkinson's disease vol II. Macmillan Healthcare Information, Florham Park, New Jersey, 1987;153-63.

6 Marc Vergnes JP, Celsis P, Montastruc JL, et al. Hémodynamique cérébrale et pharmacologie clinique dans la Maladie de Parkinson. Thérapie 1988;43:83-88.

7 Bes A, Guell A, Fabe N, Arné-Bes MC, Geraud G. Effects of dopaminergic agonists (piribedil and bromocriptine) on cerebral blood flow in parkinsonism. J Cereb Blood Flow Metab 1983;3:S490-1.

8 Harik SI. Neurotransmitter receptors in cerebral microvessels. In: Mac Kenzie ET, Seylaz J, Bes A. eds. Neurotransmitters and the Cerebral Circulation. LERS vol 2, 1984; New York, Raven Press, 1-9.

9 Sercombe R, Lacombe P, Seylaz J. Functional significance of the cerebrovascular reactivity to autonomic neurotransmitters. In: Mac Kenzie ET, Seylaz J, Bes A. eds. Neurotransmitters and the Cerebral Circulation. LERS vol 2, 1984; New York, Raven Press, 65-89.

10 Soremin OU, Sonnenschein RR, Rubinstein EH. Cholinergic cerebral vasodilatation in the rabbit: absence of concomitant metabolic activation. J Cereb Blood Flow Metab 1982;2:241-7.

11 Honer WG, Pohounik I, Smith G, Lucas LR. Scopolamine reduces frontal cortex perfusion. $J$ Cereb Blood Flow Metab 1988;8:635-41.

Address for correspondence: Dr JL Montastruc, Laboratoire de Pharmacologie Medicale et Clinique, INSERM U 317, Faculté de Medecine, 37 allées Jules Guesde, 31073 Toulouse cedex, France.

\section{Benign recurrent multiple mononeuropathy in Wegener's granulomatosis}

Sir: Neurological involvement in Wegener's granulomatosis is common, ${ }^{\prime}$ occurring in $26 \%$ of patients in a review of 374 cases. $^{2}$ In the more localised form, midline granuloma, $12 \%$ of 125 patients had neurological involvement but only one had a peripheral neuropathy. We wish to report a patient with a 5 year history of recurrent multiple mononeuropathy prior to histological diagnosis of Wegener's granulomatosis.

A 62 year old woman presented in March 1983 with a two month history of severe right frontal and temporal headache. Sinus radiographs were consistent with sinusitis. She did not improve with antibiotics and ENT opinion was that there was no significant sinus disease. ESR was $100 \mathrm{~mm}$ in 1 hour, temporal artery biopsy specimen was normal; she was referred to the neurology department and treated with prednisolone with resolution of her headache.

Four months later on prednisolone $20 \mathrm{mgs}$ per day, she developed double vision due to an almost complete right external ophthalmoplegia without ptosis. ESR was $46 \mathrm{~mm}$ in 1 hour; and her signs resolved after 5 days of prednisolone $100 \mathrm{mg}$ per day which subsequently was gradually reduced.

In November 1983, while on prednisolone $12.5 \mathrm{mg}$ per day, she developed a left vocal cord paralysis and a chest radiograph showed elevation of the left hemidiaphragm. ESR was $20 \mathrm{~mm}$ in 1 hour: mediastinal tomography, CT thorax and neck, bronchoscopy, sputum cytology, thyroid and bone isotope scans were all normal. The gradual reduction in prednisolone dosage was continued and her voice was much better one year later. She remained on $2.5 \mathrm{mg}$ prednisolone daily until March 1986 when she developed numbness and nagging pain in the left side of her face and forehead. Sensation over the left infraorbital nerve was impaired, ESR was $40 \mathrm{~mm}$ in 1 hour and sinus radiographs showed an opaque left antrum. Left maxillary antral examination revealed an absent medial wall which was attributed to previous surgery; antral washings contained polymorphs only with no malignant cells. Her symptoms improved with prednisolone $15 \mathrm{mg}$ per day. CT of her naso-pharynx revealed no other abnormality. In January 1987 on 7.5 mgs of prednisolone she developed sudden visual impairment of the left eye with pain around the orbit. Examination revealed constricted peripheral vision in the left eye with visual acuity of N48, and a left relative afferent pupillary defect. There was full recovery after one week on 30 mgs prednisolone per day, and the dose was gradually reduced.

In June 1987 because of osteoporosis the steroids were gradually reduced and discontinued six months later. In August 1988 she complained of left maxillary pain and an oro-antral fistula with erosion of all the surfaces of the maxillary antrum was found. Histology of the fistula lining showed multinucleated giant cells and necrosis surrounded by pallisading of histiocytes with necrotising vasculitis of small arteries, characteristic of Wegener's granulomatosis. She was started on cyclophosphamide $75 \mathrm{mg}$ per day and reducing doses of prednisolone, and remains well. At no stage has there been any $Z$ renal or respiratory system disorder.

This women had a 5 year history of recurrent cranial and peripheral nerve $\stackrel{\varrho}{\subseteq}$ lesions including the left optic, left infraor-ç bital, left phrenic and left recurrent laryngeal ${ }_{0}$ nerves before the diagnosis of Wegener's granulomatosis was made when an oro- $\frac{\rho}{\underline{a}}$ antral fistula developed. The initial diagnosis based on the severe headache, high ESR and. response to steroids was giant cell arteritis $\vec{Z}$ and the subsequent external ophthalmo- $\stackrel{\vec{P}}{+}$ plegia was attributed to this disorder also. The correct diagnosis probably could have been made by biopsy of antral mucosa in $\overline{\overline{\bar{S}}}$ March 1986. Any cranial nerve may be $\vec{\Phi}$ affected by Wegener's granulomatosis but ocular involvement is frequent; ${ }^{3}$ the optices neuropathy was unusual in the rapid res- $\overrightarrow{0}$ ponse to a modest dose of steroids and was.presumably due to compression by con- $\vec{\omega}$ tiguous inflammatory granulomas. The phrenic and recurrent laryngeal nerves were presumably affected by a vasculitis of the vasa nervorum and the external ophthalmoplegia may be explained by orbital muscle ? rather than third nerve involvement since 6 ptosis and pupillary abnormality were $\vec{\infty}$ absent.

This case report serves to emphasise that Wegener's granulomatosis may be a rather ${ }_{c}$ indolent process and that, in the presence $\mathcal{B} \mathrm{f}$ cranial or peripheral neuropathy, sympto of sinus disease should be fully investigat, $\overrightarrow{0}$ including biopsy.

\section{Correspondence to Dr S Kirker.} Adelaide Hospital,

Dublin 8, 르 Ireland

\section{References}

1 Drachman DA. Neurological complications of Wegener's granulomatosis. Arch Neurol? 1963;8:145-54.

2 Anderson JM, Jameson DG, Jeffersen JM. Non-healing granulomas and the nervous.system. $Q J$ Med 1974;44:309-21.

3 Haynes BF, Fishman ML, Fuci AS, Wolfe SM. The ocular manifestations of Wegener's Granulomatosis. Am J Med 1977;63:131-41. 오

Accepted 28 March 1989

Progressive systemic sclerosis presenting as a case of trigeminal neuropathy

Sir: A 58 year old shipyard welder first noticed numbness over the right lower lip in 